\title{
Digitale tekster og skriftlig fremstilling i gymnasiet - et curriculumperspektiv
}

Ulf Dalvad Berthelsen, IKK, Aarhus Universitet

\begin{abstract}
I løbet af de seneste årtier er tekster gået fra at være et overvejende analogt fænomen til at være et overvejende digitalt fænomen. I denne artikel diskuteres dels hvilke konsekvenser denne massive digitale transformation har for opfattelsen af tekster, tekstkvalitet og skriftsprog, dels de mulige implikationer for gymnasieskolens danskfag. Artiklen falder i tre dele: indledningsvis diskuteres begrebet digitale tekster med henblik på at afdække forskelle på og ligheder mellem gamle og nye teksttyper. Herefter demonstreres det gennem en række analytiske nedslag, hvordan et funktionelt perspektiv på genrer og registre dels kan danne afsæt for arbejdet med at forstå og beskrive de nye digitale tekstformer, dels kan danne afsæt for udviklingen af et begreb om tekstkvalitet, der bygger på en distinktion mellem henholdsvis succeskriterier og korrekthedskriterier. Endelig følger afslutningsvis en diskussion af, hvilke implikationer et sådant ændret perspektiv på brugen af skriftsproglige ressourcer kan og bør have for arbejdet med tekster og skriftlig fremstilling i gymnasiets danskfag.
\end{abstract}

\section{Engelsk abstract}

Over the last few decades, digital text formats have become by far the most common. In this article, I discuss the consequences of this massive digital transformation for our conception of texts and text quality, and I discuss the possible consequences for L1 writing pedagogy in secondary education. The article has three parts. Firstly, I discuss differences and similarities between digital and non-digital text formats, secondly, I show how a functional approach to text and genre analysis can lead to a better understanding of text quality, and finally, I discuss the possible implications of this view for L1 writing pedagogy in secondary education. 


\section{Indledning}

Det udvidede tekstbegreb har været en del gymnasiets danskfag siden begyndelse af 70'erne (Undervisningsministeriet, 1971). Dengang bestod udvidelsen i en accept af, at ikke blot skønlitterære tekster, men også fx film og reklamer kunne gøres til genstand for analyse med tekstteoretiske begreber og analysestrategier. Tekstbegrebet er siden blevet bredere og bredere, og ved den seneste revision af danskfagets læreplan og vejledning (Børne- og Undervisningsministeriet, u.å.) er også digitale og multimodale tekster, herunder tekster på de sociale medier, blevet skrevet ind i gymnasiets danskfag. Dette er på den ene side en positiv udvikling, men når man læser læreplan og vejledning, er det på den anden side klart, at de nye digitale genrer og teksttyper først og fremmest er skrevet ind som tekster, der skal gøres til genstand for undersøgelse og analyse. Samtidig er det også klart, at normen for skriftlig fremstilling i høj grad stadig er tekster af akademisk tilsnit, og at formel korrekthed, forstået som overholdelse af gældende standarder for dansk retskrivning, spiller en meget stor rolle i vurderingen af, hvad der er en god tekst.

Det er naturligvis ikke problematisk, at der arbejdes med den akademiske genre og med gældende standarder for retskrivning i gymnasiets danskfag. Det er imidlertid problematisk, hvis andre måder at bruge skriftsproget på, herunder de nye digitale genrer og interaktionsformer, betragtes som inferiøre og afvigende i forhold til en snæver og akademisk orienteret opfattelse af, hvad der er godt og korrekt skriftsprog. Den akademiske genre er vigtig, særligt hvis man skal være akademiker, men den er for det første ikke mere rigtig end andre genrer og teksttyper, og den er for det andet heller ikke den mest almindelige. Biber \& Egbert (2018) peger således på, at antallet af tekster på internettet er op imod 4000 gange så stort som antallet af tilgængelige tekster på verdens førende biblioteker. Ifølge siden WorldWideWebSize.com (de Kunder, u.å.) er der her ved indgangen til det 21. århundredes andet årti mere end 6 milliarder tilgængelige hjemmesider på internettet, mens fx The British Library og The American Library of Congress ifølge Biber \& Egbert (2018, s. 2) 'kun' har ca. 170 millioner registrerede materialer hver. Sammenholder man disse tal med vores daglige læse- og skrivepraksisser er det klart, at vi for det meste læser og skriver andre typer af tekster end de akademiske.

I det følgende vil jeg diskutere, hvad denne udvikling betyder for opfattelsen af skriftsprog, tekster og tekstkvalitet samt diskutere de mulige implikationer for gymnasieskolens danskfag. Artiklen falder i tre dele. Indledningsvis diskuterer jeg begrebet digitale tekster med henblik på at afdække forskelle på og ligheder mellem gamle og nye teksttyper. Herefter demonstrerer jeg gennem en række analytiske nedslag, hvordan et funktionelt perspektiv på genrer og registre dels kan danne afsæt for arbejdet med at forstå og beskrive de nye digitale tekstformer, dels kan danne afsæt for udviklingen af et begreb om tekstkvalitet, der bygger på en distinktion mellem henholdsvis succeskriterier og korrekthedskriterier. Endelig følger afslutningsvis en diskussion af, hvilke implikationer et sådant ændret perspektiv på brugen af skriftsproglige ressourcer kan og bør have for arbejdet med tekster og skriftlig fremstilling i gymnasiets danskfag.

\section{Digitale tekster}

Selvom unge, der i disse år påbegynder en gymnasial ungdomsuddannelse, ikke kan huske en hverdag uden computere, smartphones, sociale medier, digitale læremidler og digitaliserede eksamensformer, er digitale tekster set i et lidt større perspektiv et relativt nyt fænomen. I mere end 5000 år har tekster i forskellige ikke-digitale formater været dominerende, mens de tidligste digitale tekster ikke er meget mere end 50 år gamle (Fischer, 2001; Kern, 2015). Hertil kommer at det først er i kølvandet på udviklingen af internettet i løbet af 70'erne og Tim Berners-Lees opfindelse af World Wide Web sidst i 8o'erne, at digitale tekster for alvor er blevet en del af vores daglige kommunikative praksisser (Leiner et al., 2009; Biber \& Egbert, 2018). 
Som prototypiske eksempler på digitale tekster nævnes ofte de tekster, der er resultatet af vores interaktion på de sociale medier. Det kunne fx være opslag om hverdagens små og store begivenheder på Facebook, debatindlæg i kortform på Twitter, kreative hashtags på Instagram, lykønskninger på LinkedIn, kaffeinvitationer på en datingside eller diskussionstråde om klassens sukkerpolitik på skolens intranet. Disse teksttyper er vigtige, fordi de afspejler, hvordan kommunikation på de sociale medier er blevet en naturlig del af vores sproglige omgang med hinanden og for manges vedkommende også den primære anledning til i det hele taget at anvende skriftsproget. Dette fokus har dog også betydet, at meget af forskningen i digitalt medieret sprog og interaktion har haft enten en sociolingvistisk orientering mod identitet og fællesskaber (se fx Seargeant \& Tagg, 2013; Nortier \& Svendsen, 2015; Ehala, 2018) eller en lingvistisk orientering mod de mange eksotiske måder, hvorpå skriftsproget på de sociale medier afviger fra det 'normale' skriftsprog (se fx Crystal, 2001; Baron, 2008; Crystal, 2008).

Der findes imidlertid mange andre typer af digitale tekster. Disse er fx tilgængelige via forskellige typer af hjemmesider, som downloads eller via e-mail og har andre karakteristika end teksterne på de sociale medier. Dette gælder fx love og bekendtgørelser, PowerPoint-præsentationer, e-bøger, kontoudtog, lønsedler, selvangivelser, recepter, flybilletter, tv-oversigter, ansøgninger, e-mails, avisartikler, mødeindkaldelser, instruktionsbøger og skadesanmeldelser for blot at nævne nogle. Nogle af disse teksttyper er nye og findes kun i digital form, mens andre er digitale versioner af allerede kendte teksttyper. Dette rejser naturligvis spørgsmålet om, hvorvidt formatet overhovedet gør en forskel. Er det fx vigtigt, om en avisartikel udgives digitalt på avisens hjemmeside eller på tryk i papirudgaven? Er det ikke blot tale om to versioner af den samme tekst? Som vi skal se i det følgende, gør det en forskel, og med genre- og registerperspektivet bliver det også muligt mere præcist at vise, hvorfor forestillingen om, at der er tale om identiske tekster, og at digitale tekster blot er et spørgsmål om at sætte 'strøm til papir', er fejlagtig. Inden vi når så langt, er det dog nødvendigt med nogle indledende betragtninger over forskellen på digitale og ikke digitale tekster.

\subsection{Materialitet}

Spørgsmålet om, hvorvidt den samme tekst i henholdsvis digitalt og ikke-digitalt format faktisk er den samme tekst, er ikke trivielt at svare på. Svaret afhænger nemlig af, hvilket beskrivelsesniveau man vælger. Et passende teksteksempel kunne i denne sammenhæng være H. C. Andersens teknologikritiske eventyr Nattergalen, der indledes på følgende måde: "I China veed Du jo nok er Keiseren en Chineser".

Hvis vi opfatter teksternes materiale som morfemer, ord og sætninger og samtidig anlægger et klassisk strukturalistisk perspektiv på sagen (Saussure, 1931), vil en ikke-digital udgave af denne tekst, fx den der findes i førsteudgaven af Nye Eventyr (Andersen, 1844), og en digital udgave, fx Det kongelige Biblioteks faksimileudgave ${ }^{1}$ af samme, være identiske. Vi kan undersøge tegnenes indholds- og udtryksside og ordmaterialets syntagmatiske og paradigmatiske relationer og bl.a. konstatere, at 'China' betyder Kina i begge tekster, at begge tekster indledes med samme stedsadverbial i form af præpositionssyntagmet 'I China', at sætningen i begge tekster indeholder et prædikativ osv.

Opfatter vi derimod tekstens materiale som de materielle kvaliteter ved den fysiske realisering af teksten, viser der sig at være endog meget store forskelle på de to tekster. Den ikke-digitale udgave er i bogformat, nærmere bestemt oktavformat i halvbind. Materialerne er bl.a. papir, tryksværte, pap og læder. Eventyrerne i Nye Eventyr er udkommet over tid, og bindet indeholder derfor tre blokke på henholdsvis 47, 68 og 52 sider. Der er desuden et friblad mellem forsatsblad og titelblad, og teksten er

\footnotetext{
${ }^{1}$ Faksimileudgaven kan ses her: http://www5.kb.dk/e-mat/dod/130020103354.pdf
} 
sat med fraktur. Sidelayout, skrifttype og skrifttypens størrelse er statiske, da der er tale om trykte bogstaver. Bogen har dog det dynamiske element, at ratioen mellem blade til henholdsvis venstre og højre side kan ændre sig. Dette sker i takt med, at der bladres i bogen, hvorved oplevelsen af bindets fysiske dimensioner forandres. Først tynd til venstre og tyk til højre, senere tyk til venstre og tynd til højre.

For den digitale faksimileudgave forholder det sig modsat. Her er den fysiske genstand, fx computerskærm, tablet-computer eller smartphone, statisk, mens tekstvisningen er dynamisk. Den digitale enhed består typisk af glas, plastik, aluminium og en række elektroniske komponenter, og enhedens fysiske dimensioner forandrer sig ikke under læsningen. Man bladrer ikke, men navigerer i stedet $\mathrm{i}$ teksten ved at bruge mus, tastatur eller ved at berøre enhedens skærm. Man kan på denne måde zoome ind og ud og scrolle op og ned mellem siderne. Teksten er desuden ocr-behandlet, hvilket muliggør søgning i teksten samt markering, kopiering og indsætning af kommentarer.

Disse afgørende forskelle er direkte konsekvenser af de to udgavers materielle kvaliteter. I bogudgaven er teksten realiseret gennem en proces, hvor tryksværte, via en trykform, er påført papiret. Når trykket er tørt, optræder papir og tryksværte som en enhed, og sidens layout og grafiske udtryk er herefter uforanderligt, med mindre det fysisk manipuleres, fx ved hjælp af en saks eller en kuglepen. Ved faksimileudgaven sker der imidlertid ikke en sådan sammensmeltning mellem tekst og fysisk genstand. Her realiseres teksten ved, at pdf-filen, der indeholder en digitaliseret version af den affotograferede bog, via et program installeret på den digitale enhed, vises på enhedens skærm. Både pdf-filen og applikationen er lagret på enheden som magnetiske eller elektriske spor, der repræsenterer binære kodesekvenser. Når applikationen afvikles, omsættes kodesekvenserne til elektriske impulser, der får skærmens lysdioder til at lyse. De bogstaver, vi ser på skærmen, eksisterer således ikke permanent, men kun som midlertidige konfigurationer af lysende dioder.

Som det fremgår af sammenligningen, er de to udgaver af Nattergalen både ens og meget forskellige. De er ens set fra et grammatisk og tekstlingvistisk perspektiv, ligesom de også er ens fra et indholdsmæssigt perspektiv, hvilket let vil kunne vises gennem en sammenlignende litterær analyse ${ }^{2}$. De er til gengæld væsensforskellige set fra et materielt perspektiv, og det er netop denne materielle forskel, der giver anledning til de betydelige forandringer af skriftsprog og kommunikative praksisser, der er fulgt med de seneste årtiers digitale udvikling (Harris, 2001; Berry, 2012). Mere præcist kan man sige, at tekst og materiale ikke længere udgør en uopløselig enhed, fordi den teknologiske udvikling har muliggjort en adskillelse af form (hardware), medie (software) og indhold (tekstfil), og at denne frigørelse har skabt nye kommunikative handlemuligheder (Hutchby, 2001, 2014).

\footnotetext{
2 Pladsen tillader ikke en udtømmende diskussion af dette spørgsmål, og det er heller ikke direkte relevant for diskussionen af forskellen på digitale og ikke-digitale tekster, men der er naturligvis også en grænse for lighed på det strukturelle niveau. I originaludgaven er teksten som nævnt sat med fraktur og retskrivningen følger konventioner fra før retskrivningsreformen (Bekendtgørelse om ændringer i retskrivningen, 1948), og man kan derfor spørge sig selv, i hvilket omfang teksten kan ændres før den bliver en anden tekst. Er det fx den samme tekst, hvis skrifttypen erstattes med mere moderne typer som Times New Roman eller Palatino? Er det den samme tekst, hvis vi retter 'China' til 'Kina', 'veed' til 'ved' og 'Chineser' til 'kineser'? Er det den samme tekst, hvis den optræder i en illustreret udgave? Er det den samme tekst, hvis den læsebearbejdes med henblik på yngre læsere?
} 


\subsection{Produktion og distribution}

En væsentlig konsekvens af denne udvikling er, at betingelserne for produktion og distribution af tekster har ændret sig radikalt. Det at skrive og dele tekster var indtil for nylig forbundet med meget omstændelige og ressourcekrævende arbejdsprocesser. Selv hvis man ser bort fra sumeriske kiler prentet på lertavler, runer ristet i granit eller møjsommeligt fremstillede illuminerede håndskrifter og vender blikket mod det 20. århundredes teksttyper, er det klart, at der har været tale om krævende processer3. Et brev måtte fx skrives i hånden, puttes i en frankeret kuvert, transporteres til en postkasse, transporteres fra postkassen til en postcentral og fra centralen til det lokale posthus, og herefter bringes ud med bud. Bøger, aviser, magasiner og lignende måtte (og må stadig) på samme måde renskrives, typograferes, trykkes, distribueres til boghandlere, biblioteker, kiosker og derfra distribueres videre til læserne (lånerne/køberne/forbrugerne). I modsætning hertil produceres og distribueres digitale tekster meget let4. Bøger må nødvendigvis distribueres i mange eksemplarer, mens uendeligt mange digitale tekster kan distribueres til fx en e-bogslæser på en smartphone. Hertil kommer, at alle nu uden videre kan producere og distribuere tekster, $\mathrm{fx}$ ved hjælp af relativt simple tekstredigeringsværktøjer (fx Word eller Pages), ved hjælp af Amazons selvudgiver-service, ved hjælp af e-mail-programmer og onlinetjenester ( $\mathrm{fx}$ Outlook, Gmail, Google Drev eller Google Docs) eller ved hjælp af de tekstredigeringsmoduler, der er indbygget i brugergrænsefladerne til de mange sociale medier ( $\mathrm{fx}$ Facebook eller Twitter) og blogging-værktøjer (fx Wordpress, Wix eller Blogger).

Merchant (2007, s. 118) omtaler disse nye måder at producere og forbruge tekst som 'post-typographic literacies'. Med dette hentydes der til det forhold, at vi har bevæget os fra en situation, hvor de fleste publicerede tekster var skrevet, redigeret og udgivet af professionelle, til en situation, hvor de færreste publicerede tekster er skrevet, redigeret og udgivet af professionelle. Ikke forstået sådan at der nødvendigvis publiceres færre tekster skrevet, redigeret og udgivet af professionelle, men forstået sådan at der nu, jf. Biber \& Egberts (2018) tidligere omtalte opgørelse, publiceres ekstremt mange flere tekster, der ikke er skrevet, redigeret og udgivet af professionelle. Samtidig henviser udtrykket også til det forhold, at digitale tekster, modsat ikke-digitale tekster, er søgbare, kopierbare, delbare og redigerebare i et omfang, der ikke gælder ikke-digitale tekster. Tekster er derfor blevet mere flydende i den forstand, at de, som fx et Wikipedia-opslag, forandrer sig over tid, fordi flere skriver med, eller at de i fragmenteret form bliver del af andre tekster, fordi det, fx ved hjælp af digitale klippe/klistre-værktøjer, er blevet let at integrere dele af tekster i nye tekster, fx blog-indlæg eller opslag og kommentarer på de sociale medier.

\subsection{Multimodalitet}

Endnu en vigtig forskel på digitale og ikke digitale tekster er, at det digitale format gør det let at arbejde multimodalt. Modaliteter forstås i denne sammenhæng som forskellige typer af kommunikative ressourcer. I den klassiske funktionelle grammatik skelnes der mellem modaliteterne tale og skrift (Halliday \& Hasan, 1976; Halliday, 1978, 1985), men i nyere fortolkninger bruges begrebet bredere

\footnotetext{
${ }^{3}$ Det er vigtigt at bemærke, at det ikke nødvendigvis er blevet nemmere eller mindre ressourcekrævende samlet set. Det kommer an på, hvor man befinder sig i produktions- og distributionssystemet. Det er fx dyrt at udvikle og vedligeholde internettets infrastruktur. Bemærkningerne ovenfor går derfor først og fremmest på de ændrede kommunikative handlemuligheder.

${ }^{4}$ Naturligvis bortset fra den intellektuelle anstrengelse, det ofte er at skrive. Dette aspekt af tekstproduktionen er selvsagt meget vigtigt, også i et pædagogisk og didaktisk perspektiv, og de digitale formater bidrager på forskellig vis til at gøre skriveprocessen lettere eller vanskeligere afhængigt af forfatterens temperament, digitale færdigheder mv. Det ligger dog ikke inden for rammerne af denne artikel, at behandle dette aspekt yderligere.
} 
(Leeuwen, 2005; Kress, 2006, 2010). Dette brede modalitetsbegreb indbefatter dels en opmærksomhed på, at en tekst er en kompleks størrelse, og at fx skriftstørrelse og sideopsætning også er kommunikative ressourcer, der bidrager til tekstens samlede udtryk, dels en inkluderende tolkning af begrebet, således at også lyd, farver, figurer, levende billeder med mere opfattes som selvstændige modaliteter.

Tekster har naturligvis altid været multimodale, og illustrationer, tabeller og diagrammer findes i selv meget tidlige manuskripter, fx i Euclid fragmentet Papyrus Oxyrhynchus 295, der menes at være knap 2000 år gammelt og i Book of Kells, den irske pragtudgave af evangelierne, der menes at være omtrent 1100 år gammel ${ }^{6}$. Det er således ikke brugen af andre kommunikative ressourcer end tekst, der i sig selv adskiller digitale tekster fra ikke-digitale tekster. Det gør derimod det forhold, at det er meget nemt at integrere andre modaliteter end tekst i digitale tekster.

Dette ses let, hvis man sammenligner det traditionelle feriepostkort med en opdatering på et af de sociale medier, fx Facebook. Postkortet er en klassisk multimodal teksttype, der i bogstaveligste forstand består af en billedside og en tekstside. Idet billedet er påtrykt kortet, kan der for det første ikke integreres mere end ét billede, og valget kan for det andet ikke ændres, når postkortet først er indkøbt. På kortets anden side er der plads til til at skrive en kort besked, evt. elaboreret med små tegninger, fx håndtegnede smileyer. I et Facebook-opslag kan der til sammenligning integreres adskillige fotografier, ligesom der også kan indlejres videoklip og link til andre online-ressourcer. I teksten kan der desuden integreres en lang række billedtegn i form af fx smileyer, emojier og GIF'er, alt sammen blot ved nogle få tryk på tastaturet. Et andet eksempel, der tydeligt illustrerer forskellen på, i hvilket omfang digitale og ikkedigitale tekster tillader integration af forskellige modaliteter, er sammenligningen af en avisartikel i en trykt avis og en avisartikel tilgængelig som digital tekst på avisens hjemmeside. I den trykte udgave kan der anvendes tekst og billeder, evt. i farver, mens der i den digitale online udgave kan anvendes tekst og billeder, men også videoklip, animationer og lyd, herunder muligheden for at få læst teksten op.

Mange andre eksempler kunne have været nævnt. PowerPoint-præsentationer og digitale boardingkort er fx også teksttyper, hvis modale konfiguration er markant forskellige fra deres ikke-digitale pendanter, og de illustrerer alle, hvordan forskellen er direkte knyttet teksternes materialitet. Hvor trykte formater er begrænset til først og fremmest at bruge visuelle modaliteter, betyder digitaliseringen, at alle modaliteter, der kan digitaliseres, dvs. omsættes til binære kodesekvenser og transmitteres til en anden enhed, kan anvendes i forbindelse med produktion af digitale tekster.

\subsection{Kommunikative handlemuligheder}

Vi har nu set, hvordan digitale tekster adskiller sig fra ikke-digitale tekster på tre vigtige områder, nemlig med hensyn til deres materialitet, med hensyn til betingelserne for produktion og distribution, og med hensyn til, hvilke modaliteter det er muligt at bringe i spil. Samtidig fremgår det også af gennemgangen, at der er tale om tre sider af samme sag, nemlig at digitaliseringen har forandret vores kommunikative handlemuligheder, hvilket, teknisk understøttet af stigende hastighed og øget kapacitet, har forandret vores kommunikative praksisser.

\footnotetext{
${ }^{5}$ Fragmentet kan ses på Penn Museums hjemmeside: https://www.penn.museum/collections/object/63505

${ }^{6}$ Book of Kells kan ses på Trinity College's universitetsbibliotek i Dublin.
} 
Begrebet kommunikative handlemuligheder trækker på Gibsons (1979) oprindelige begreb om handlemuligheder7 (affordances), der betegner det forhold, at der, idet vi interagerer med vores omgivende miljø, opstår forskellige handlemuligheder afhængigt af dels miljøets beskaffenhed, dels vores egen konstitution og fysiske dimensioner. Gibson havde som udgangspunkt fokus på vores naturlige omgivelser, men Hutchby (2001) har siden peget på, at der også gennem interaktionen med artefakter, herunder digitale teknologier, opstår handlemuligheder. Nogle af disse handlemuligheder kan betegnes som kommunikative. Det kan de i de tilfælde, hvor resultatet af at udnytte dem er kommunikation. I mødet med en kasse af passende størrelse opstår der en mulighed for at træde op på den og derved blive i stand til at nå noget på øverste hylde. Resultatet af at udnytte denne mulighed er ikke kommunikativt. Det er det derimod, hvis man ved at berøre skærmen på sin smartphone udnytter de virtuelle muligheder for at sende en smile-smiley til en ven.

Kommunikative handlemuligheder er naturligvis ikke bundet til digitale teknologier. Digitalt medierede handlemuligheder er blot en særlig type af kommunikative handlemuligheder. Hutchby (2014) peger i denne forbindelse på, at al kommunikation er, og altid har været, medieret, dels gennem tale og skrift, dels gennem forskellige teknologier, digitale såvel som ikke-digitale. Begrebet om kommunikative handlemuligheder er således vigtigt, fordi det bidrager til en generel forståelse af relationen mellem kommunikativt handlende individer og den kontekst, hvori de handler, herunder en forståelse af hvilken rolle forskellige typer af teknologier spiller i forhold til at understøtte den ene eller den anden type kommunikative praksis i den ene eller den anden type kontekst. Understøttes fx synkrone eller asynkrone praksisser, ansigt-til-ansigt-kommunikation eller massekommunikation osv.?

\section{Kontekst, register, genre og tekstkvalitet}

At undersøge de kommunikative handlemuligheder i en given kontekst er at undersøge betingelserne for kommunikativ praksis i denne kontekst. For at kunne gøre dette har vi dels brug for nogle begreber til at beskrive centrale træk ved konteksten, dels brug for nogle begreber, der kan beskrive de lingvistiske træk ved de kommunikative praksisser, der udfolder sig i denne kontekst. Disse begreber kan med fordel hentes fra funktionelt orienterede tilgange til sprogbeskrivelse. I det følgende trækker jeg derfor på Hallidays (1978) kontekstbegreb, Bibers (1995) registerbegreb, og Swales' (1990) genrebegreb. Da genstanden for denne undersøgelse alene er tekster (i bred forstand) og derfor ikke indbefatter mundtlig kommunikation, følger jeg Togeby (2014) og omtaler kommunikative handlinger udført ved hjælp af skriftsproget som teksthandlinger.

\subsection{Kontekst}

Inden for rammerne af den funktionelle lingvistik forstås kontekster som konkrete situationer, der rammesætter og former kommunikative praksisser. For at beskrive hvordan konteksten former disse praksisser skelner Halliday (Halliday, 1978, 1985) mellem tre forskellig kontekstuelle aspekter: field, tenor og mode 8 . Field dækker over emner og aktivitetstyper knyttet til en konkret praksis. Hvad foregår der, og hvad tales der om? Et af den funktionelle lingvistiks yndlingseksempler er læge/patientsamtalen: Lægen stiller spørgsmål, patienten svarer, og der tales om symptomer, behandlingsformer og

\footnotetext{
${ }^{7}$ På dansk bruges nogle gange udtrykket 'affordanser'. Her foretrækkes imidlertid det mere informative 'handlemuligheder'. Se i øvrigt Berthelsen \& Tannert (2020), for en mere udførlig diskussion af begrebet.

${ }^{8}$ Forskellige ikke-mundrette danske oversættelser har været foreslået. Der er imidlertid ikke konsensus, og jeg har derfor valgt for klarhedens skyld at beholde de engelske betegnelser.
} 
receptpligtig medicin. Tenor betegner de individer, der er en del af situationen, herunder deres relationer til hinanden og de roller, de indtager i situationen. Hvem deltager, og hvad er deres status? Der er således en formelt og institutionaliseret relation mellem læge og patient, hvor patienten efterspørger en ydelse, som kun den autoriserede læge kan tilbyde. Endelig betegner mode sprogets rolle i situationen. Hvilke kommunikative ressourcer er til rådighed, fx tale, skrift eller andre modaliteter, og hvilken rolle spiller de? Både lægen og patienten taler i forbindelse med konsultationen, og lægen anvender måske skriftsproget til at udskrive en recept eller grafer og tabeller til at anskueliggøre behandlingsforløbet.

Der er naturligvis andre træk ved den konkrete kommunikationssituation, der kan have indflydelse på, hvordan en given praksis udfolder sig, fx temperaturen i rummet, belysningen eller tidspunktet på dagen. Disse er imidlertid tilfældige aspekter ved situationen, der ikke på samme måde som field, tenor og mode systematisk rammesætter og former den sprogligt medierede interaktion?.

\subsection{Register}

Begrebet register dækker over de konkrete sproglige valg, der træffes i relation til en given kontekst. Registret kommer således til udtryk gennem de konkrete form- og indholdsvalg, sprogbrugere træffer i konkrete kommunikationssituationer. Ud over denne generelle beskrivelse er der imidlertid hverken enighed om, hvad der skal forstås ved register, eller hvordan det relaterer sig til begreber som fx genre og stil (de Beaugrande, 1993; Biber \& Conrad, 2009). Halliday \& Hasan (1976) og Halliday (1978) repræsenterer i relation til dette spørgsmål en teoretisk funderet tilgang, der betragter registre som de forudsigelige sproglige valg, der knytter sig til specifikke typer af situationer. I modsætning hertil repræsenterer Biber (1995), Biber (2006) og Biber \& Egbert (2018) en korpusbaseret tilgang, der sigter efter empirisk at karakterisere forskellige registre på baggrund af konkrete lingvistiske træk. I det følgende læner jeg mig op ad Bibers tilgang. Ikke i den forstand, at den aktuelle undersøgelse er korpusbaseret, men i den forstand, at jeg vil fokusere på konkrete lingvistiske træk ved den digitalt medierede kommunikation med henblik på at forstå diversiteten blandt de digitale teksttyper. Formålet er således ikke at forudsige, hvilke sproglige valg der træffes i en given kontekst, men at forsøge at forstå teksttypen ud fra de sproglige valg, der er truffet.

\subsection{Genre}

Genrebegrebet er ligesom registerbegrebet omdiskuteret. Fx opfatter Halliday (1985) genre som et underbegreb til registerbegrebet, mens fx Martin (1992) og Martin \& Rose (2008) betragter det som et overbegreb i den forstand, at genre ikke bestemmes af lokale sprogbrugssituationer, men derimod formes i en bredere kulturel kontekst. De er dog enige om, at genrer er produktet af sociale praksisser i sociale kontekster. Et alternativ til dette genresyn finder vi hos Swales (1990), der opfatter genrer som klasser af formålsorienterede sociale handlinger, dvs. handlinger defineret ved deres ekstralingvistiske succeskriterier ${ }^{10}$. Dette skal forstås sådan, at konteksten (field, tenor, mode) ganske vist former teksters konkrete udtryk, men at det afgørende kriterium for, om to tekster tilhører samme genre, er, hvorvidt de har samme type af succeskriterier. Samtidig peger Swales på, at der kan være betydelig formmæssig

\footnotetext{
${ }^{9}$ Men de kan selvfølgelig i ekstreme tilfælde inddrages som virkemiddel, fx når forhørslederen forsøger at presse den mistænkte til at tale ved at dæmpe lyset i afhøringslokalet og blænde ham med bordlampen.

${ }^{10}$ Halliday og Martin og mange andre funktionalister trækker på konstruktivistisk tankegods, mens Swales i højere grad har et realistisk afsæt. Hvor dybt denne forskel stikker lader sig imidlertid ikke afgøre inden for rammerne af denne undersøgelse.
} 
variation inden for de enkelte genrer, idet grupperinger og undergrupperinger sker på baggrund af de enkelte teksters mere eller mindre prototypiske genretræk. Fx deler victoriatidens sirlige kærestebreve ikke mange formmæssige træk med nutidens Tinderbeskeder (for eksempler se Hemmingsen, 2017). Ikke desto mindre tilhører de sammen genre, idet succeskriteriet for begge er, at afsenderen får en date.

\subsection{Succeskriterier}

I det følgende trækker jeg alene på Swales' genrebegreb. Dette skyldes for det første, at genrebestemmelse på baggrund af teksthandlingens ekstralingvistiske succeskriterier er en velegnet indgang til at forstå variationerne både mellem og inden for de forskellige digitale teksttyper. For det andet skyldes det, at dette afsæt giver en klar indikation af, at korrekthedskriterier forstået som overholdelse af gældende normer for dansk retskrivning ikke kan stå alene som vurderingskriterium for en teksts kvalitet.

En teksthandlings primære succeskriterium kan opfattes som en parallel på tekstniveau til talehandlingers betingelser for tilfredsstillelse (Searle, 1969). Assertiver er tilfredsstillede, hvis de er sande, direktiver hvis de efterleves osv. På samme måde er kærestebreve succesfulde, hvis man får en kæreste, ansøgninger hvis man får jobbet, og indkøbssedler hvis man husker det hele. Sammenlignes denne type kriterier med korrekthedskriterier for retskrivning, bliver det klart, at korrekthedskriterier, set fra et funktionelt perspektiv, aldrig kan stå alene. Med mindre der er tale om en test, fx en grammatikprøve, kan korrekthedskriterier aldrig være de primære succeskriterier for en teksthandling. Dette betyder naturligvis ikke, at korrekthed ikke er vigtigt, men det betyder, at korrekthed, snarere end at være et mål i sig selv, er et middel til at sikre succesen af visse typer teksthandlinger. Ansøger man fx om en stilling som dansklærer på et gymnasium, er det sandsynligt, at formel korrekthed spiller en relativt stor rolle, mens det formentlig spiller en mindre rolle, hvis man søger en stilling som ungarbejder i et supermarked. I sidst nævnte tilfælde kan det måske ligefrem være diskvalificerende, hvis brugsuddeleren får mistanke om, at den formelle korrekthed skyldes, at ansøgningen er skrevet af ansøgerens forældre.

Det vil også ofte være tilfældet, at der i en given kontekst er en forventning om, at bestemte genrekonventioner overholdes, $\mathrm{fx}$ at videnskabelige artikler udstyres med henvisninger og litteraturliste. Disse genrekonventioner er imidlertid ikke genredefinerende i samme forstand som de primære succeskriterier, idet de i modsætning til de primære succeskriterier forandrer sig over tid. Det er desuden vigtigt at være opmærksom på, at udførelsen af en teksthandling kan have andre ekstralingvistiske succeskriterier end de primære genredefinerende kriterier. Formålet med at skrive en ansøgning og få et job kan fx være at tjene penge med henblik på at komme ud at rejse, og formålet med at oplyse om ens motionsvaner på det sociale medier kan være at iscenesætte sig selv på en bestemt måde. På denne måde indgår al kommunikation i omfattende netværk af praktiske og strategiske handlinger med henblik på at nå mange forskellige mål. Alle disse mål er vigtige og i mange tilfælde også den egentlige anledning til udførelsen af en given teksthandling (se fx Askehave \& Swales, 2001). Som det er tilfældet med genrekonventionerne er disse mål imidlertid ikke genredefinerende, og når der i det følgende tales om en teksthandlings succeskriterier, er det derfor udelukkende de primære genredefinerende succeskriterier, der henvises til.

\section{Analytiske nedslag}

I de foregående afsnit har jeg præsenteret en række begreber, der med fordel kan anvendes i arbejdet med at beskrive og forstå, hvordan digitaliseringen påvirker vores kommunikative praksisser, herunder særligt hvordan den påvirker tekster og teksthandlinger. Nedenfor følger tre analytiske nedslag som eksempel. De tre tekster er valgt med henblik på at demonstrere mangfoldighed, men er samtidig alle tre typiske for deres genre. Det første eksempel er et opslag om skadedyrsbekæmpelse hentet fra en 
kommunal hjemmeside. Det andet eksempel er en salgsannonce hentet fra en kommerciel side, der primært formidler køb og salg mellem private. Det sidste eksempel er et spillesteds aflysning af en koncert hentet fra deres profil på et socialt medie. Alle tre eksempler er indsamlet i januar 2020. Eksemplerne er hentet på frit tilgængelige hjemmesider, og teksterne er gengivet præcis som de stod. Dog er navne, stednavne og telefonnumre blevet fjernet.

De tre analytiske nedslag er organiseret skematisk, og følger alle samme struktur. Først beskrives de kontekstuelle faktorer (field, tenor og mode), hvorefter teksten genrebestemmes. Herefter følger selve teksten, og endelig beskrives teksterne i forhold til materialitet, produktion og distribution samt udnyttelsen af kommunikative handlemuligheder.

\subsection{Rottebekæmpelse}

\begin{tabular}{|c|c|c|c|}
\hline $\begin{array}{l}\text { Field: } \\
\text { Skadedyrsbekæmpelse, } \\
\text { rotter. Kommunen } \\
\text { informerer om service, } \\
\text { herunder ret og pligt. Der } \\
\text { informeres også om konkrete } \\
\text { handlemuligheder i tilfælde } \\
\text { af skadedyr. }\end{array}$ & \multicolumn{2}{|c|}{$\begin{array}{l}\text { Tenor: } \\
\text { Formaliseret relation. } \\
\text { Skadedyrsbekæmpelse } \\
\text { betales over skatten. } \\
\text { Kommunen har pligt til } \\
\text { håndtere problemet. } \\
\text { Borgerne har pligt til at } \\
\text { anmelde tilfælde af skadedyr. } \\
\text { Servicen er udliciteret, så } \\
\text { selve bekæmpelse udføres af } \\
\text { et privat firma efter aftale } \\
\text { med borgeren. }\end{array}$} & $\begin{array}{l}\text { findes på } \\
\text { neside, så } \\
\text { er } \\
\text { t i teksten } \\
\text { ink. Dette }\end{array}$ \\
\hline \multicolumn{2}{|c|}{$\begin{array}{l}\text { Overgenre: } \\
\text { Det offentlige informerer om servicetilbud, } \\
\text { herunder ret og pligt. } \\
\text { Undergenre: } \\
\text { Information om skadedyrsbekæmpelse med } \\
\text { henblik på bekæmpelse. }\end{array}$} & \multicolumn{2}{|c|}{$\begin{array}{l}\text { Primært succeskriterium: } \\
\text { Effektiv bekæmpelse af rotter i lokalområdet. } \\
\text { Korrekthed: } \\
\text { Inkonsekvent kommatering. Anden linje } \\
\text { indledes med en atypisk formulering, hvor } \\
\text { 'har' får en dobbeltrolle, idet infinit verbal og } \\
\text { objekt ('set eller mistanke') sideordnes. } \\
\text { 'Indenfor' i et ord. }\end{array}$} \\
\hline \multicolumn{4}{|c|}{$\begin{array}{l}\text { Tekst: } \\
\text { I XXX Kommune er det firmaet YYY, der står for rottebekæmpelsen. } \\
\text { Har du set eller mistanke om rotter på din ejendom skal det anmeldes HER. } \\
\text { Rottebekæmperen vil komme på tilsynsbesøg senest } 8 \text { dage efter din anmeldelse, men du vil } \\
\text { som regel blive kontaktet på det opgivne telefonnummer indenfor } 48 \text { timer. Hvis din } \\
\text { henvendelse drejer sig om rotter i indendørs opholdsrum, er det særlig vigtig med en hurtig } \\
\text { indsats. Derfor kan du forvente at blive kontaktet indenfor } 24 \text { timer. } \\
\text { Skal du have hjælp til at anmelde dit rotteproblem kan du kontakte Den Digitale Hotline på } \\
\text { oo oo oo oo. }\end{array}$} \\
\hline \multicolumn{4}{|c|}{$\begin{array}{l}\text { Register: } \\
\text { Tonen er saglig og formel (rottebekæmpelse, tilsynsbesøg, indendørs opholdsrum), men } \\
\text { samtidig ligefrem og handlingsorienteret (skal anmeldes, vil komme, hurtig indsats). Brugen } \\
\text { af modalverber understreger, at der er tale om en ret-og-pligt-relation. }\end{array}$} \\
\hline \multicolumn{4}{|c|}{$\begin{array}{l}\text { Materialitet: } \\
\text { Teksten findes kun i digital form og ligger frit tilgængeligt på kommunens hjemmeside. } \\
\text { Teksten kan tilgås fra alle typer af computere med internetforbindelse, herunder } \\
\text { smartphones og tablet-computere. }\end{array}$} \\
\hline
\end{tabular}




\section{Produktion og distribution:}

Teksten er både produceret og distribueret digitalt, formentlig uden andre mellemled end den digitale mediering mellem den medarbejder, der har forfattet teksten, og den borger, der læser teksten. Teksten er distribueret via kommunens eget internetdomæne.

\section{Kommunikative handlemuligheder:}

Den digitale teknologi gør det muligt på en nem og ressourcebesparende måde at producere og distribuere væsentlig information til mange ukendte modtagere.

\subsection{Salgsannonce}

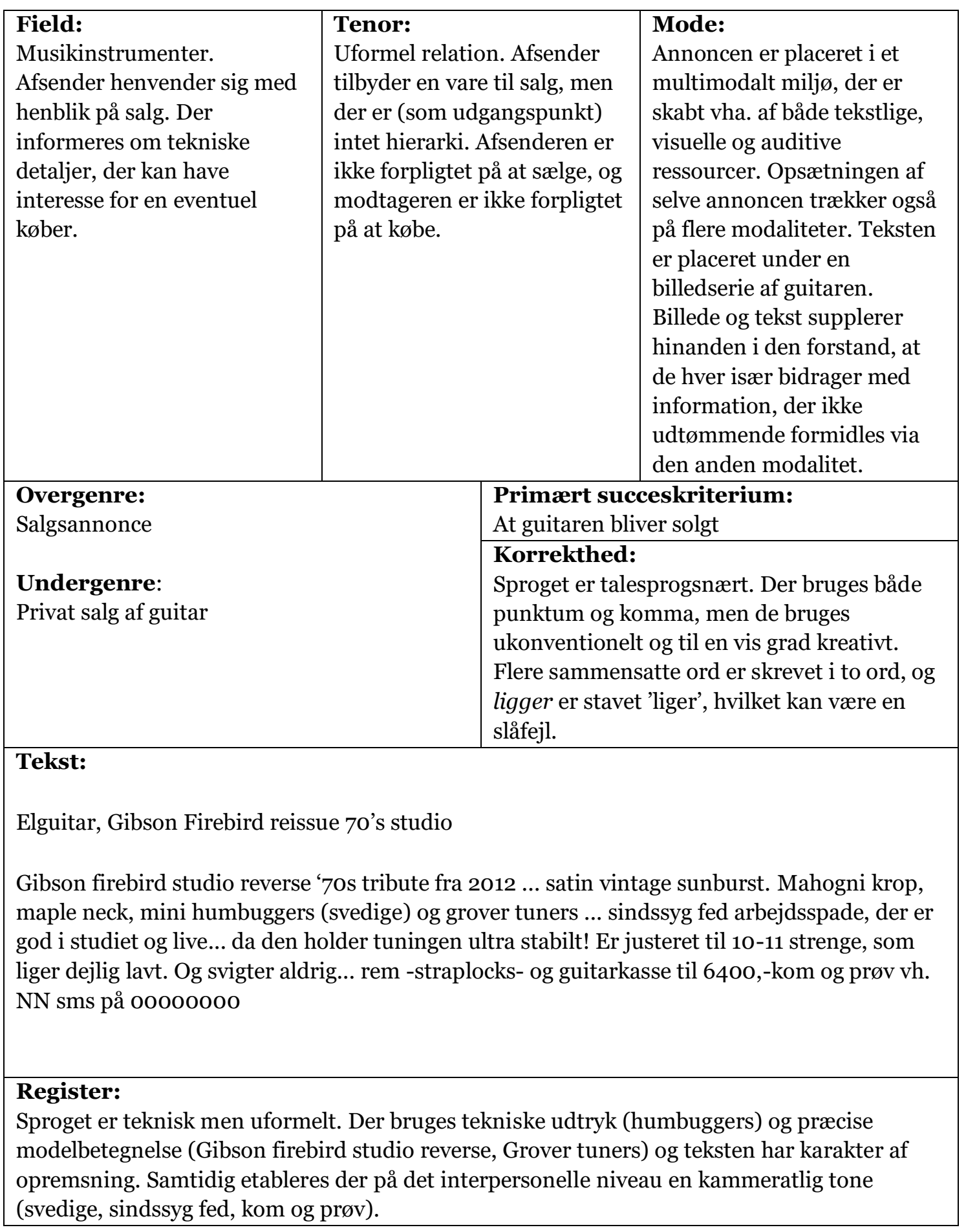




\section{Materialitet:}

Teksten findes kun i digital form og ligger frit tilgængeligt på salgsportal. Teksten kan tilgås fra alle typer af computere med internetforbindelse, herunder smartphones og tabletcomputere.

\section{Produktion og distribution:}

Teksten er både produceret og distribueret digitalt, formentlig uden andre mellemled end den digitale mediering mellem sælger og eventuelle købere. Teksten er distribueret via en kommerciel hjemmeside, der formidler købs- og salgsannoncer.

\section{Kommunikative handlemuligheder:}

Den digitale teknologi gør det muligt på en nem og ressourcebesparende måde at producere og distribuere tilbud om køb og salg til en stor gruppe potentielle købere.

\subsection{Opslag om aflysning}

\begin{tabular}{|c|c|c|}
\hline $\begin{array}{l}\text { Field: } \\
\text { Musik, koncert. Et spillested } \\
\text { informerer gæsterne om dels } \\
\text { at koncerten er aflyst, dels } \\
\text { årsagen til aflysningen. }\end{array}$ & $\begin{array}{l}\text { Tenor: } \\
\text { Der er en kontraktlig relation } \\
\text { mellem afsender og } \\
\text { modtager, idet modtagerne } \\
\text { af beskeden har betalt for } \\
\text { billetten til den aflyste } \\
\text { koncert. }\end{array}$ & $\begin{array}{l}\text { Mode: } \\
\text { Tekst er den primære } \\
\text { modalitet. Teksten findes } \\
\text { som opslag på spillestedets } \\
\text { sociale medie-profil, så } \\
\text { rammen om teksten er } \\
\text { multimodal. Internt i teksten } \\
\text { findes der et hyperlink. Dette } \\
\text { er markeret med blå } \\
\text { tekstfarve. Anvendelse af } \\
\text { grafiske virkemidler er } \\
\text { minimal. } \\
\text { Og bortset fra linket og } \\
\text { spillestedets logo er der ikke } \\
\text { brugt andre kommunikative } \\
\text { ressourcer. }\end{array}$ \\
\hline $\begin{array}{l}\text { Overgenre: } \\
\text { Aflysning }\end{array}$ & \multicolumn{2}{|c|}{$\begin{array}{l}\text { ressourcer. } \\
\text { Primært succeskriterium: } \\
\text { At gæsterne til den aflyste koncert ikke } \\
\text { møder op. }\end{array}$} \\
\hline $\begin{array}{l}\text { Undergenre: } \\
\text { Koncertaflysning }\end{array}$ & & $\begin{array}{l}\text { Korrekthed: } \\
\text { Ingen afvigelser }\end{array}$ \\
\hline \multicolumn{3}{|c|}{$\begin{array}{l}\text { Tekst: } \\
\text { Her for kort tid siden har vi desværre haft en mindre brand i XXX. Ingen er kommet til skade, } \\
\text { og situationen er heldigvis under kontrol. } \\
\text { Aftenens koncert med NN bliver dog desværre aflyst. }\end{array}$} \\
\hline \multicolumn{3}{|c|}{$\begin{array}{l}\text { Register: } \\
\text { Sagligt og ligefremt. Afdæmpet tone (mindre brand, ingen er kommet til skade, under } \\
\text { kontrol). Der udtrykkes beklagelse (2x desværre) }\end{array}$} \\
\hline \multicolumn{3}{|c|}{$\begin{array}{l}\text { Materialitet: } \\
\text { Teksten findes kun i digital form og ligger frit tilgængeligt på spillestedets sociale medie- } \\
\text { profil. Teksten kan tilgås fra alle typer af computere med internetforbindelse, herunder } \\
\text { smartphones og tablet-computere. }\end{array}$} \\
\hline \multicolumn{3}{|c|}{$\begin{array}{l}\text { Produktion og distribution: } \\
\text { Teksten er både produceret og distribueret digitalt, formentlig uden andre mellemled end den } \\
\text { digitale mediering mellem spillested og gæster. Teksten er distribueret via et socialt medie. }\end{array}$} \\
\hline
\end{tabular}




\section{Kommunikative handlemuligheder:}

Den digitale teknologi gør det muligt på en nem og ressourcebesparende måde at producere og distribuere vigtig information til mange modtagere.

\subsection{Analytiske pointer}

Der er som nævnt tale om analytiske nedslag, hvilket betyder, at de enkelte punkter på ingen måde er behandlet udtømmende. Alligevel er det dog muligt at gøre nogle iagttagelser på tværs af de tre eksempler.

Set fra et funktionelt perspektiv er der tale om relativt traditionelle teksttyper, der alle kendes fra ældre ikke-digitale formater. Der er tydelige afsender/modtager-relationer og tydelige rollefordelinger ${ }^{11}$. Brugen af andre modaliteter end tekst er stærkt begrænset. Kun i salgsannoncen spiller billederne en væsentlig rolle $\mathrm{i}$ forhold til at sikre teksthandlingens succes. De tre tekster er alle nemme at genrebestemme i den forstand, at de alle tre har tydelige og entydige primære succeskriterier. Der er også klart, at der inden for en overgenre kan være betydelig variation blandt undergenrerne. Dette stemmer dels overens med Swales' genredefinition, dels med den funktionelle forståelse af register som valg af ressourcer relativt til konteksten.

Det er også bemærkelsesværdigt, at både opslaget på den kommunale hjemmeside og salgsannoncen i betydelig grad afviger fra normerne for dansk retskrivning, uden at der i øvrigt er noget, der tyder på, at disse afvigelser i særlig grad forhindrer afsenderen $i$ at nå sine ekstralingvistiske mål. Registrene varierer meningsfuldt relativt til de respektive kontekster, og der er ingen eksempler på brud i forhold til den forventede registerbrug.

I forhold til de digitale aspekter er de tre tekster også meget ens. Alle tre tekster eksisterer kun i digital form og medieres af mainstream hardware-teknologier (computer, smartphone, tablet). De er alle produceret digitalt, formentlig uden professionelles redaktørers mellemkomst, og distribueret via store velkendte platforme (kommunal hjemmeside, kommerciel salgsportal, socialt medie). Alle teksterne har en en/få til mange-relation mellem afsender og modtager, og det er derfor oplagt at tro, at valget netop derfor er faldet på et digitalt format. De kommunikative handlemuligheder ved den digitalt medierede kommunikation overgår i alle tre tilfælde de ikke-digitale alternativer ( $\mathrm{fx}$ at hænge et opslag op hos købmanden).

\section{Tekster og skriftlig fremstilling i gymnasiets danskfag}

Omdrejningspunktet for denne artikel har været tre centrale pointer. For det første lever vi i de digitale teksteres tidsalder. Langt den største del af de tekster, vi producerer og konsumerer i forbindelse med vores daglige kommunikative praksisser, er digitale. For det andet er teksttyper knyttet til de sociale medier kun en del af de mange digitale tekster, vi dagligt producerer og konsumerer. For det tredje er korrekthed, forstået som overholdelse af normer for retskrivning, ikke det vigtigste succeskriterium for

\footnotetext{
${ }^{11}$ Der er naturligvis også altid andre tilstede i kommunikationssituationen. Fx andre kommunale medarbejdere, annoncører og platformejere. Der er derfor også altid mange andre interesser på spil end de direkte involverede aktørers interesser. Det ligger dog uden for rammerne af denne fremstilling af udrede disse forhold.
} 
udførelsen af en teksthandling i dagligdags kommunikative praksisser. Tværtimod er det et middel til at nå teksthandlingens ekstralingvistiske mål. Dette gælder generelt for alle typer af tekster, men er, som vi har set, særlig tydeligt i forbindelse med produktion og konsumption af digitale tekster i dagligdags kommunikative praksisser.

Vender vi herefter blikket mod gymnasiets danskfag og de styredokumenter, der rammesætter det (Børne- og Undervisningsministeriet, u.å., 2019a), er det tydeligt, at denne nye virkelighed kun delvist er skrevet ind i faget. Der tales ganske vist om multimodalitet, digitale fællesskaber, sociale medier og digital literacy, og produktion af multimodale tekster og medietekster har også fået en plads. Der er imidlertid en række centrale passager i læreplan og vejledning, der klart indikerer, at danskfaget stadig i høj grad er domineret af en klassisk skolsk ${ }^{12}$ tekstforståelse. Fx er skriftlighed i forbindelse med opstilling af fagets mål beskrevet med et klart fokus på korrekthed og akademisk orienterede fremstillingsformer (Børne- og Undervisningsministeriet, 2017, s. 1): "[eleverne skal kunne] beherske skriftsprogets normer for korrekthed og anvende grammatiske og stilistiske grundbegreber" og "[eleverne skal kunne] anvende centrale skriftlige fremstillingsformer (herunder redegøre, diskutere, analysere, fortolke og vurdere) med formidlingsbevidsthed".

En anden klar indikation findes i det forhold, at skrivning eksplicit kobles til læring og studieforberedelse (Børne- og Undervisningsministeriet, 2019a, s. 20):

\begin{abstract}
"Arbejdet med elevernes skriftlige og mundtlige udtryksfærdighed er tæt knyttet til det tekstanalytiske arbejde. Det betyder, at eleverne producerer kortere eller længere tekster i timerne - enten i forlængelse af eller som led i fx præsentationen af et fagligt stof eller et analytisk arbejde. Det afgørende er, at eleverne oplever fagets dimensioner som integrerede størrelser. I oplevelsen af, at der er klar sammenhæng mellem fx tekstanalyse, skriftlighed og mundtlighed, øges muligheden for, at eleven omsætter sin danskfaglige viden i sine tekstproduktioner, ligesom muligheden, for at eleven oplever skrivning som et åbnende refleksionsværktøj i tekstanalytisk sammenhæng, øges. Det er vigtigt, at der både arbejdes med skrivning som målbar dokumentation af basale og studieforberedende færdigheder og som redskab for udforskning, udvikling og læring."
\end{abstract}

I passagen ovenfor anlægges der det, man kunne kalde for et metafunktionelt perspektiv på skrivning. Der er ikke klart definerede og funktionelt orienterede ekstralingvistiske succeskriterier for denne type teksthandling. Der er til gengæld metasucceskriterier, nemlig læring og studieforberedelse. At der er tale om to forskellige typer af succeskriterier ses let af det forhold, at succes på det metafunktionelle niveau ikke er afhængig af succes på det funktionelle niveau (eller omvendt). Når skriftlig fremstilling således eksplicit kobles til metafunktionelle succeskriterier, er det klart, at denne type tekster vil blive prioriteret i undervisningen.

Endelig er der i forbindelse med udprøvningen et entydigt fokus på det metafunktionelle. Den skriftlige prøve er centreret om genren 'artikel', og eleven har tre valgmuligheder: den analyserende, den debatterende og den reflekterende artikel. En første udfordring er, at en artikel i et funktionelt perspektiv ikke er en genre, men et format, idet det at betegne noget som en artikel alene siger noget om forventet længde og distributionskanal, men ikke noget om succeskriterierne. En anden udfordring ved dette format er, at der ikke er nogen autentisk modtager, hvilket faktisk anerkendes i vejledningen (Børne- og Undervisningsministeriet, 2019a, s. 30). Uden klart formål, uden klar genrespecifikation og

12 'Skolske' genrer er Vibeke Hetmars (2011) betegnelse for genrer, der kun praktiseres i skolen. 
uden en autentisk modtager, sker der det, at de funktionelle succeskriterier erstattes af metafunktionelle succeskriterier.

I forlængelse af Swales' genredefinition blev det diskuteret, hvordan klare ekstralingvistiske succeskriterier muliggør stor variation på registerniveau. Når de funktionelle succeskriterier erstattes af metafunktionelle succeskriterier, sker der imidlertid det modsatte. I dette tilfælde sker der det, at de ekstralingvistiske succeskriterier erstattes med lingvistiske succeskriterier i den forstand, at det at producere et vellykket eksempel på en tekst fra en bestemt genre kommer til at handle om at demonstrere kendskab til specifikke genretræk, herunder struktur, fremstillingsformer og danskfaglige begreber. At det forholder sig sådan i gymnasiets danskfag, kan man forvisse sig om ved at læse de sidste mange sider af vejledningen, der i detaljer beskriver, hvilke formelle krav der stilles til en 'artikel'.

\section{Konklusion}

Spørgsmålene, der dannede afsæt for denne undersøgelse, var følgende: 1) hvad betyder den digitale udvikling for vores opfattelse af skriftsproget og af tekstbegrebet? 2) hvad er tekstkvalitet? og 3) hvad betyder svarene på disse spørgsmål for gymnasiets danskfag? Til det første spørgsmål er svaret, at den digitale udvikling har betydet, at skriftsproget i dag indtager en langt mere centrale rolle i vores daglige aktiviteter end tidligere, og at tekster bør opfattes som funktionelle enheder, der kan anvendes mere eller mindre succesfuldt i uendeligt mange forskellige sammenhænge med henblik på at nå ekstralingvistiske mål. Til det andet spørgsmål er svaret at tekstkvalitet i et funktionelt perspektiv først og fremmest må vurderes i relation til teksthandlingens succeskriterier. En god tekst er en tekst, der godt og effektivt bidrager til, at sprogbrugeren når sine ekstralingvistiske mål. Dette kan nemt misforstås i retning af, at fx en teksts formelle eller æstetiske kvaliteter så ikke spiller en rolle. Dette er imidlertid langtfra tilfældet. Tekster kan have alle tænkelige slags ekstralingvistiske formål, herunder også at underholde, at skabe oplevelser, at gøre samtalepartnere glade, sure, misundelige osv. I disse tilfælde er det meget sandsynligt, at netop tekstens formelle og æstetiske kvaliteter er afgørende for at opfylde teksthandlingens succeskriterier. Pointen er blot, at korrekthed og æstetik altid vil være midler, og aldrig målet i sig selv. Endelig - og med største respekt for den meget store opgave det er at dække litteratur, sprog og medier i både et synkront og diakront perspektiv - er svaret på det tredje spørgsmål, at gymnasiets danskfag i højere bør tage konsekvenserne af de seneste årtiers digitale omvæltninger alvorligt. Dels ved tydeligere at skrive de nye digitale betingelser for kommunikativ handlen frem i de styredokumenter, der rammesætter faget, dels ved at lade en bredere vifte af genrer og teksthandlingstyper indgå i den skriftlige prøve, således at elevernes skriftsproglige kompetencer ikke, sådan som det er i dag, først og fremmest bedømmes ud fra metafunktionelle succeskriterier.

\section{Referencer}

Andersen, H. C. (1844). Nattergalen. I Nye Eventyr. Reitzels Forlag.

Askehave, I., \& Swales, J. M. (2001). Genre identification and communicative purpose: A problem and a possible solution. Applied Linguistics, 22(2), 195-212. https://doi.org/10.1093/applin/22.2.195

Baron, N. S. (2008). Always on: Language in an online and mobile world. Oxford University Press.

Berry, D. M. (2012). Introduction: Understanding the Digital Humanities. I D. M. Berry (Red.), Understanding Digital Humanities (1st ed. 2012., s. 1-20). Palgrave Macmillan UK.

Berthelsen, U. D., \& Tannert, M. (2020). Utilizing the affordances of digital learning materials. L1 - Educational Studies in Language and Literature, 2O, 1-23. https://doi.org/10.17239/L1ESLL-2020.20.02.03

Biber, D. (1995). Dimensions of register variation: A cross-linguistic comparison. Cambridge University Press.

Biber, D. (2006). University language: A corpus-based study of spoken and written registers. JBenjamins.

Biber, D., \& Conrad, S. (2009). Register, genre, and style. University Press.

Biber, D., \& Egbert, J. (2018, august). Register Variation Online. Cambridge Core.

https://doi.org/10.1017/9781316388228 
Børne- og Undervisningsministeriet. (u.å.). Stx-Læreplaner 2017. Hentet 7. januar 2020 fra https://www.uvm.dk:443/gymnasiale-uddannelser/fag-og-laereplaner/laereplaner-2017/stx-laereplaner$\underline{2017}$

Børne- og Undervisningsministeriet. (2017). Stx-Læreplaner. Hentet 7. januar 2020 frahttps://www.uvm.dk:443/gymnasiale-uddannelser/fag-og-laereplaner/laereplaner-2017/stx-laereplaner$\underline{2017}$

Børne- og Undervisningsministeriet. (2019a). Dansk A, stx. Vejledning. Hentet 7. januar 2020 fra https://www.uvm.dk:443/gymnasiale-uddannelser/fag-og-laereplaner/laereplaner-2017/stx-laereplaner$\underline{2017}$

Børne- og Undervisningsministeriet. (2019b). Råd og Vink 2019-Til de nye genrer, skriftlig dansk stx. EMU.dk. Hentet 7. januar 2020 fra https://emu.dk/sites/default/files/201910/R\%C.3\%A5d\%200g\%20vink\%202019\%20Dansk\%20A\%2OHf\%20\%28002\%29.pdf

Crystal, D. (2001). Language and the internet. Cambridge University Press.

Crystal, D. (2008). Txtng: The Gr8 Db8. Oxford University Press.

de Beaugrande, R. (1993). "Register" in discourse studies: A concept in search of a theory. I M. Ghadessy (Red.), Register analysis: Theory and Practice. Pinter Publishers.

de Kunder, M. (u.å.). WorldWideWebSize.com|The size of the World Wide Web (The Internet). Hentet 13. januar 2020, fra https://www.worldwidewebsize.com/

Ehala, M. (2018). Social Media, Culture, and Identity Construction: From Mass Communication to Communication of the Masses. Routledge.

Fischer, S. R. (2001). A history of writing. Reaktion Books.

Gibson, J. J. (1979). The ecological approach to visual perception. Houghton Mifflin.

Halliday, M. A. K. (1978). Language as social semiotic: The social interpretation of language and meaning. Edward Arnold.

Halliday, M. A. K. (1985). An introduction to functional grammar. Edward Arnold.

Halliday, M. A. K., \& Hasan, R. (1976). Cohesion in English. Longman.

Harris, R. (2001). Rethinking writing. Continuum.

Hemmingsen, A. (2017). Den store Tinderbog: 200 gale eller geniale scoringsfors $\varnothing g$ på Tinder.. People'sPress.

Hetmar, V. (2011). Kommunikationsformer som didaktisk kategori. Cursiv, 7(2), 75-96.

Hutchby, I. (2001). Technologies, Texts and Affordances. Sociology, 35(2), 441-456. https://doi.org/10.1177/So038038501000219

Hutchby, I. (2014). Communicative affordances and participation frameworks in mediated interaction. Journal of Pragmatics, 72, 86-89.

Kern, R. (2015). Language, Literacy, and Technology. Cambridge University Press.

Kress, G. (2006). Literacy in the new media age. Routledge.

Kress, G. (2010). Multimodality: A social semiotic approach to contemporary communication. Routledge.

Leeuwen, T. van. (2005). Introducing social semiotics. Routledge.

Leiner, B. M., Cerf, V. G., Clark, D. D., Kahn, R. E., Kleinrock, L., Lynch, D. C., Postel, J., Roberts, L. G., \& Wolff, S. (2009). A Brief History of the Internet. SIGCOMM Comput. Commun. Rev., 39(5), 22-31. https://doi.org/10.1145/1629607.1629613

Lov om dansk retskrivning. LOV nr. 332 af 14/o5/1997, (1997). Hentet 7. januar 2020 fra https://www.retsinformation.dk/Forms/Ro710.aspx?id=84769

Martin, J. R. (1992). English text: System and structure. John Benjamins.

Martin, J. R., \& Rose, D. (2008). Genre relations: Mapping culture. Equinox.

Merchant, G. (2007). Writing the future in the digital age. Literacy, 41(3), 118-128. https://doi.org/10.1111/j.1467-9345.2007.00469.x

Nortier, J., \& Svendsen, B. A. (2015). Language, youth and identity in the 21st century: Linguistic practices across urban spaces. Cambridge University Press.

Saussure, F. de. (1931). Cours de linguistique générale (A. Sechehaye, A. Riedlinger, \& C. Bally, Red.). Payot.

Seargeant, P., \& Tagg, C. (2013). The language of social media: Identity and community on the Internet. Palgrave Macmillan.

Searle, J. R. (1969). Speech acts: An essay in the philosophy of language. Cambridge University Press.

Swales, J. M. (1990). Genre analysis: English in academic and research settings. Cambridge University Press.

Togeby, O. (2014). Bland blot genrerne-Ikke tekstarterne!: Om sprog, tekster og samfund. Samfundslitteratur.

Undervisningsministeriet. (1971). Bekendtgørelse om undervisningen i gymnasiet og fordringerne ved og eksamensopgivelserne til studentereksamen. Nr. 322 af 16. Juni 1971. (Inkl. Andringer via bekendtgørelse nr. 19 af 23. Januar 1975, nr. 186 af 1. April 1976 og nr. 662 af 15. December 1977). Undervisningsministeriet. 


\section{Forfatter}

\section{Ulf Dalvad Berthelsen}

Lektor

Aarhus Universitet

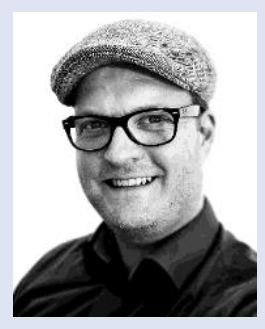

